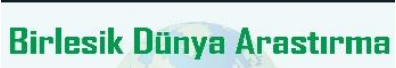 BD C CENTER \\ Innovasyon ve Yayıneılık Merkezi \\ New Trends and Issues Proceedings on Humanities and Social Sciences}

Volume 7, Issue 1 (2020) 186-193

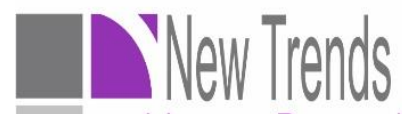

and Issues Proceedin! on Humanities \& Social Scienc

www.prosoc.eu

Selected Paper of 12th World Conference on Educational Sciences (WCES-2020) 06-08 June 2020, Istanbul Ayvansaray University, Istanbul, Turkey

\title{
Understanding of sustainable development in terms of environmental ethics: A qualitative study
}

Şenol Şen ${ }^{\mathrm{a}}$, Hacettepe University, Faculty of Education, Beytepe, Ankara, 06800, Turkey https://orcid.org/00000001-6050-4794

Senar Temel ${ }^{\text {b }}$, Hacettepe University, Faculty of Education, Beytepe, Ankara, 06800, Turkey https://orcid.org/00000003-3831-3953

\section{Suggested Citation:}

Sen, S. \& Temel, S., (2020). Understanding of sustainable development in terms of environmental ethics: A qualitative study. New Trends and Issues Proceedings on Humanities and Social Sciences. 7(1) pp 186-193. DOI: 10.18844/prosoc.v\%vi\%i.4892

Received from October 15, 2019; revised from March 3,2020; accepted from June 25, 2020.

Selection and peer review under responsibility of Assoc. Prof. Dr. Jesus Garcia Laborda, University of Alcala, Spain. C2020 Birlesik Dunya Yenilik Arastirma ve Yayincilik Merkezi. All rights reserved.

\begin{abstract}
This study aims to determine prospective teachers' understanding of sustainable development concept in the context of environmental ethics approach. Qualitative research method was used. A total of 20 prospective teachers were participated to the study and they were selected by purposeful sampling method. A test comprised of two open-ended questions was used for collecting data. The test was applied to the participants and they were required to answer the questions in writing in 20 minutes. Prospective teachers' written answers to the test questions were analysis according to content analysis. The findings obtained through content analysis were divided into codes and then categories and themes were defined. After the analysis of the themes and categories, prospective teachers' understanding of sustainable development concept in the context of environmental ethics approach was revealed and then the findings were discussed in details.
\end{abstract}

Keywords: content analysis, environmental ethics, prospective teachers, sustainable development, understanding

\footnotetext{
*ADDRESS FOR CORRESPONDENCE: Şenol Şena, Hacettepe University, Faculty of Education, Beytepe, Ankara, 06800, Turkey
} E-mail address: schenolschen@gmail.com 
Sen, S., \& Temel, S., (2020). Understanding of sustainable development in terms of environmental ethics: A qualitative study. New Trends and Issues Proceedings on Humanities and Social Sciences. 7(1) pp 186-193

\section{Introduction}

The concept of sustainable development is a new concept that emerged in the 1970s and shows an understanding that economic development can also be environmentally oriented (Yıldırım \& Nuri, 2018). The transition of sustainability from thought to concept occurred as a result of the large-scale destruction caused by economic and social developments to ecosystem in the twentieth century. The fact that the ontological continuity of the global society is faced with the threat of extinction caused a strong environmental movement in the 1970s (Bozlağan, 2010). On the other hand, parallel to the increase in the world population, growth efforts in the world economy brought with it environmental problems and created an imbalance between the economy and the environment. The increase in environmental pollution has directed Western societies to protect the global environment since 1980s. Increasing interest in the environment caused the desire to find solutions to eliminate the negativities between economic growth and environmental balance (Kaypak, 2011). So the concept of sustainable development (SD) gained international acceptance when it was included in the document prepared by International Union for Conservation of Nature and Natural Resources (IUCN, 1980) for the first time and then defined in the report prepared by World Commission on Environment and Development (WCED, 1987) (Summers, Corney, \& Childs, 2004). The concept of SD is based on a consensus of the environmental worldview with the developmental view. It can be said that the concept has become the main discourse of environmental and development movements today (Bozlağan, 2010). As stated by Clarin, (2018), SD concept has two basic elements; development and sustainability. Just as these two words that form the concept of sustainable development was defined differently from different perspectives, the concept of SD was also viewed from different perspectives and different definitions of the concept were made (Mensah, 2019). SD was defined as the process of meeting today's needs without making compromises with meeting the needs of next generations in the report (WCED, 1987). It was also defined as securing the rational management of natural resources in a way to protect humans' health, not to disturb natural balance and to sustain continuous economic development and thus to leave a liveable natural, physical and social environment to next generations (Guzel, Coknaz, \& Atalay Noodegraaf, 2009). Sustainable development is only possible with a sustainable environment. Environmental sustainability, on the other hand, means maintaining natural resources (Kaypak, 2011; Fagbayide \& Abulude, 2018).

As stated in the Bruntland report (WCES, 1987) the concept of SD has 3 targets. These are (1) the protection of environment, (2) providing economic development and maintaining it and (3) ensuring social welfare (Cokisler \& Cokisler, 2017). Also while examining the definition of sustainable development, it is seen that it is addressed in many dimensions within the scope of different sciences (Arpacıoğlu Özdemir \& Oğuz, 2018). SD has three aspects labelled as ecological, economic and social. They are interconnected and interrelated (Karpudewan, Ismail, \& Mohamed, 2009). In other words, sustainable development in a country will be achieved by ensuring ecological sustainability, economic sustainability and social sustainability. In the sustainable development concept; four key issues are addressed together under the name of social and economic policies, management of natural resources, environmental protection and the needs of future generations (Alagöz, 2004). According to Clarin (2018), three basic element of SD concept were suggested in its development process. These are (1) the concept of development (socioeconomic development consistent with ecological restriction), (2) the concept of needs (redistribution of resources to ensure everyone's quality of life) and 3) the concept of next generations (the possibility of a long-term usage of resources to ensure the necessary quality of life for next generations). The concept of SD recommended a holistic approach to development containing economic, social and ecological dimensions, and it put forward the idea of an ethical approach arguing that it would be a fair behaviour for today's people to make sacrifices for next generations. Thus, the concept of SD argues for the 
Sen, S., \& Temel, S., (2020). Understanding of sustainable development in terms of environmental ethics: A qualitative study. New Trends and Issues Proceedings on Humanities and Social Sciences. 7(1) pp 186-193

conception of ethics, which attaches importance to the protection of ecocentric ethical values (Ergun \& Cobanoglu, 2012).

The concept of ethics is an important factor in the solution of environmental problems, with awareness and sensitivity aimed at the change in human behaviour. Environment ethics, on the other hand, can be defined as a theoretical discipline that examines all kinds of attitudes and behaviours that may be effective in the relations of human with nature and natural elements and the decisions to be made regarding the environment (Karaca, 2008). Sustainable development can be interpreted in the context of the approach of environmental ethics as considering the effects of behaviour on next generations while acting the behaviour. Individuals have to live in harmony with the living and non-living things- the other components of the ecosystem in which the individual lives (Ergun \& Cobanoglu, 2012). Indeed, environmental ethics encourages people to display behaviours beneficial to the environment rather than behaviours harmful to the environment, which can be labelled as bad or wrong behaviours (Ercis \& Turk, 2016). Thus, individuals need to question what is good and what is bad in their behaviours towards the ecosystem. With individuals' avoidance of behaviours, which may give harm to the ecosystem, a world in which next generations will be able to meet their needs without making compromises will be left to them. From an ethical point of view, a behaviour that does not take into account the next generations, reduces or eliminates the welfare of next generations, cannot be accepted as a good behaviour even if it benefits today's generations. In other words, while displaying behavior, it is to take into account the effect of this behavior on next generations. If these were done, a good behavior was generally performed in the context of ethics and environmental ethics; otherwise, bad behavior will be exhibited (Ergun \& Cobanoglu, 2012).

The individuals who have adopted environmental ethics will act by taking into consideration the consequences of their behaviours before displaying the behaviours, which are harmful to the environment (Ercis \& Turk, 2016; Burgin, 2018). In this way, they will avoid behaviours harmful to the environment. The individuals who are expected to adopt environmental ethics in the society are mainly teachers. In other words, it is necessary to train teachers who have environmental ethics because they are the ones who will raise next generations. Therefore, it would be beneficial in this paper to identify prospective teachers' understanding of sustainable development concept in the context of environmental ethics approach who will be the direct implementers of curricula. It is because it is believed that the results obtained in this study will function as a guide in preparing the programmes for training teachers who have environmental ethics.

\subsection{The aim of the study}

This study aims to determine prospective teachers' understanding of sustainable development concept in the context of environmental ethics approach.

\section{Method}

The study is a qualitative study. The qualitative research method was conducted for describing or answering questions about particular, localized occurrences of contexts and the perspectives of a participant group towards events, beliefs of practices (Gay \& Airasian, 2000).

\subsection{Study group}

A total of 20 prospective teachers were participated to the research as a study group. They were selected by purposeful sampling method. Purposeful sampling is a method enabling researchers to examine the situations having rich information in depth and thus to illuminate better the questions that a study focuses on (Patton, 2002). While selecting the participants, volunteering was considered. 
Sen, S., \& Temel, S., (2020). Understanding of sustainable development in terms of environmental ethics: A qualitative study. New Trends and Issues Proceedings on Humanities and Social Sciences. 7(1) pp 186-193

Participants were given some information related to the characteristics of the study such as the content of the study, data collection, data analysis and confidentiality of their names.

\subsection{Data collection tool}

A test comprised of two open-ended questions was developed in line with the aim of the study by the researchers. The data related to the sustainable development and environmental ethics approach was collected via the test. Literature review was conducted while preparing the test questions. The test was comprised of questions related to the relationship between sustainable development and environmental ethics and which environmental ethics approach the concept of sustainable development serves. The test was applied to the participants in the 2019-2020 academic year. They were required to answer the questions in writing in 20 minutes.

\subsection{Analyses of the data}

Prospective teachers' written answers to the test questions were analysis according to content analysis. The aim of the content analysis is to reach the concepts and relations, which would be able to explain the data collected (Yıldırım \& Şimşek, 2011). In the first step of content analysis codes were created from collected data. Secondly, study data were analysed in categories and then themes were formed. Thirdly, we tried to consult expert opinion for ensuring internal validity of the study. While coding, similarities and differences between the researchers and expert were contrasted. Then interrater reliability was computed as $90 \%$. According the some studies conducted by Miles and Huberman, (1994) and Yıldırım and Şimşek, (2011) interrater reliability above $70 \%$ should be attained at the minimum in qualitative studies.

\section{Results}

The findings obtained through content analysis are shown in Table 1 and 2.

Table 1: Content analysis findings related to the relationship between sustainable development and environmental ethics

\begin{tabular}{|c|c|c|c|c|c|}
\hline \multirow{2}{*}{\multicolumn{6}{|c|}{ 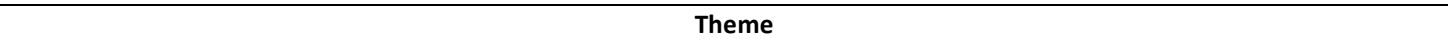 }} \\
\hline & & & & & \\
\hline \multicolumn{6}{|c|}{$\begin{array}{l}\text { The relationship between sustainable development and environmental ethics } \\
\text { Categories }\end{array}$} \\
\hline $\begin{array}{l}\text { Ecocentric environmental ethics } \\
\text { approach }\end{array}$ & & $\begin{array}{c}\text { Living organism-centred ethics } \\
\text { approach }\end{array}$ & & Anthropocentric ethical approach & \\
\hline Codes & f & Codes & $f$ & Codes & $\mathbf{f}$ \\
\hline $\begin{array}{l}\text { Understanding that needs are } \\
\text { unlimited but resources are limited }\end{array}$ & 7 & $\begin{array}{l}\text { Protecting living organisms and } \\
\text { transmitting them down to next } \\
\text { generations }\end{array}$ & 1 & $\begin{array}{l}\text { Protecting natural resources and } \\
\text { transmitting them down to next } \\
\text { generations }\end{array}$ & 10 \\
\hline Establishing social justice globally & 6 & & & $\begin{array}{l}\text { Achieving economic development by } \\
\text { considering next generations }\end{array}$ & 6 \\
\hline Using natural resources consciously & 5 & & & $\begin{array}{l}\text { Moral responsibilities for next } \\
\text { generations }\end{array}$ & 3 \\
\hline $\begin{array}{l}\text { Developing without loading nature } \\
\text { the pollution that it cannot bear }\end{array}$ & 3 & & & $\begin{array}{l}\text { Benefits of protecting the } \\
\text { environment for humans }\end{array}$ & 1 \\
\hline Respecting nature & 2 & & & & \\
\hline $\begin{array}{l}\text { Permitting the renewal of natural } \\
\text { resources }\end{array}$ & 2 & & & & \\
\hline $\begin{array}{l}\text { Protecting nature and living and } \\
\text { non-living things }\end{array}$ & 2 & & & & \\
\hline $\begin{array}{l}\text { Considering humans as a part of } \\
\text { nature }\end{array}$ & 1 & & & & \\
\hline Using renewable resources & 1 & & & & \\
\hline Organic farming practice & 1 & & & & \\
\hline Green economy activities & 1 & & & & \\
\hline Environment protection projects & 1 & & & & \\
\hline
\end{tabular}


Sen, S., \& Temel, S., (2020). Understanding of sustainable development in terms of environmental ethics: A qualitative study. New Trends and Issues Proceedings on Humanities and Social Sciences. 7(1) pp 186-193

Prospective teachers' understandings on the relationships between sustainable development and environmental ethics were considered in 3 categories. An examination of their views in the category of ecocentric environmental ethics demonstrated that $35 \%$ of them attracted attention to understanding that needs were unlimited but that resources were limited, $30 \%$ of them attracted to establishing social justice globally, $25 \%$ of them to using the resources consciously, $15 \%$ to developing without loading nature the pollution that it could not bear, $10 \%$ to respecting nature, to permitting the renewal of natural resources and to protecting nature and living and non-living things and $5 \%$ to considering humans as a part of nature, to using renewable resources, to organic farming practice, to green economy activities and to environment protection projects. A prospective teacher's statement about the protection of living organisms and transmitting them down to next generations was considered in the category of living organism-centred ethics approach since the statement laid emphasis on living organisms. On examining the statements made in the category of anthropocentric ethical approach, it was found that half of the participants $(50 \%)$ stressed protection of natural resources and transmitting them down to next generations, $30 \%$ of them stressed achieving economic development by considering next generations and that $15 \%$ stressed moral responsibilities for next generations. Only one participant stated that it was beneficial for humans to protect the environment.

Table 2: Content analysis findings related to which environmental ethics approach the concept of sustainable development serve

\begin{tabular}{llll}
\hline \multicolumn{2}{c}{ Which environmental ethics approach the concept of sustainable development serves } \\
& Categories & Anthropocentric ethical approach \\
\multicolumn{1}{c}{ Ecocentric environmental ethics approach } & & & $\mathbf{f}$ \\
\hline Codes & $\mathbf{f}$ & Codes & 6 \\
Valuing living and non-living things & 5 & Leaving natural resources to next generations & 5 \\
Balanced use of natural resources & 4 & Sustainability of the environment to serve humans & 3 \\
Valuing nature & 3 & Thinking of next generations & 2 \\
Permitting nature to renew itself & 2 & Leaving a liveable world to next generations & 2 \\
Not polluting nature more than it can bear & 2 & Making sacrifices for next generations & 1 \\
Protection of natural resources & 2 & Reflections of anthropocentric ethical approach & \\
\hline
\end{tabular}

As is clear from Table 2, prospective teachers think that sustainable development serves to two different approaches of ethics. Accordingly, in the category of ecocentric environmental ethics approach $25 \%$ of the prospective teachers stated views on valuing living and non-living things, $20 \%$ stated views on balanced use of natural resources, $15 \%$ on valuing nature, $10 \%$ on permitting nature to renew itself, on not polluting nature more than it could bear and on the protection of natural resources. Their statements about leaving natural resources to next generations (30\%), sustainability of the environment to serve humans (25\%), thinking of next generations (15\%), sacrificing for next generations $(10 \%)$ and the reflections of anthropocentric ethical approach (5\%), on the other hand, were considered in the category of anthropocentric ethical approach.

\section{Conclusion and Discussion}

On examining prospective teachers' understanding of sustainable development in the context of environmental ethics, it was found that they interpreted sustainable development in 3 approaches of ethics. Their views about protecting nature, living things and non-living things, respecting nature, using natural resources consciously, understanding that the resources were limited, permitting the renewal of natural resources, achieving development without loading nature the pollution that it could not bear and 
Sen, S., \& Temel, S., (2020). Understanding of sustainable development in terms of environmental ethics: A qualitative study. New Trends and Issues Proceedings on Humanities and Social Sciences. 7(1) pp 186-193

establishing social justice globally in the category of ecocentric environmental ethics approach indicated that they had awareness and understanding of the environment. In the same way, the specific views they had stated in relation to considering humans as a part of nature, the need of using renewable resources, organic farming practice, green economy activities and environment protection projects were also the desirable results obtained in this study. Only one participant stated a view about protecting living organisms in the category of living organism-centred ethics approach. Their views on protecting natural resources and transmitting them down to next generations, achieving development by thinking of next generations, moral responsibilities for next generations and benefits of protecting the environment for humans could be interpreted as that protecting the environment and natural resources in accordance with benefits it could provide next generations- that is to say, humans- emphasised anthropocentric ethical approach.

It was found in this study that prospective teachers' understandings on which environmental ethics approach the concept of sustainable development served were divided into 2 approaches of ethics. They emphasised ecocentric environmental ethics approach with their views on valuing nature, permitting nature to renew itself, not polluting nature more than it could bear, protecting natural resources, balanced use of natural resources and valuing living and non-living things- for which the interpretation could be a positive ethics approach that should be adopted. However, the number of prospective teachers stating those views was small. Their views on leaving a liveable world to next generations, sacrificing for next generations, leaving natural resources to next generations, thinking of next generations and sustainability of the environment for humans were considered in the category of anthropocentric ethical approach in that they stressed the need for protecting nature by thinking of next generations.

A general evaluation of the results demonstrates that prospective teachers interpreted the concept of sustainable development mostly on the basis of ecocentric environmental ethics approach- which was a desirable result. However, the fact that the number of participants who stated their views in this respect was small that should be taken into consideration. Besides, they were also found to interpret the concept of sustainable development in the context of anthropocentric ethical approach only by thinking of next generations. It was a result which was consistent with the criticisms made for the concept of sustainable development. Ergun and Cobanoglu (2002) reported that the most important criticism made for the concept was its' emphasis on anthropocentric ethical approach. In the same vein, Cokisler and Cokisler (2017) also argue that anthropocentric ethical approach sets up the human-environment relationships through a wrong connection.

\section{Recommendations}

It is thought that the results of our study will shed light on what should be done to understand the sustainable development concept correctly. When the criticisms made for sustainable development are taken into consideration, it is seen that the opinions of prospective teachers are in parallel with these criticisms. However what is desired is the adoption of an environmental ethics approach in achieving sustainable development. In this regard, protecting natural resources should not be considered only within the scope of human benefit, but also within the scope of ensuring both ecological balance and balance between human and nature. At this point, educational institutions and especially trainers have great duties because they have an important role in students' or prospective teachers' understanding of sustainable development concept correctly. It is expected that courses related to the environment will be included more in the curriculum, and these courses will take place at an appropriate level for students at 
Sen, S., \& Temel, S., (2020). Understanding of sustainable development in terms of environmental ethics: A qualitative study. New Trends and Issues Proceedings on Humanities and Social Sciences. 7(1) pp 186-193

all levels from preschool education to higher education. It is important to include not only theoretical knowledge about the environment, but also out-of-school activities that will encourage students to practice themselves.

\section{References}

Alagöz, M. (2004). Sürdürülebilir kalkınmanın paradigması. The Journal of Social Economic Research, 4(8), 1-23. Retrieved from https://dergipark.org.tr/tr/pub/susead/issue/28434/302878.

Arpacıoğlu Özdemir, Ö., \& Oğuz, i. H. (2018). A case of poverty from the perspective of sustainable development. The Journal of International Social Research, 11(55). Doi: http://dx.doi.org/10.17719/jisr.20185537248.

Bozlağan, R. (2010). Sürdürülebilir gelişme düşüncesinin tarihsel arka plani. Journal of Social Policy Conferences, $\quad 0(50), \quad$. 1011-1028 Retrieved from https://dergipark.org.tr/tr/pub/iusskd/issue/891/9943.

Burgin, A. (2018). The implementation of EU environmental policy: Why the scope conditions have improved?. World Journal of Environmental Research, 8(1), 1-7. https://doi.org/10.18844/wjer.v8i1.3944

Clarin, T. (2018). The concept of sustainable development: From its beginning to the contemporary issues. Zagreb International Review of Economics \& Business, 21(1), 67-94. Doi: 10.2478/zireb-2018-0005.

Cokisler, N., \& Cokisler, E. (2017). Critics of the concept of the sustainable development. International Journal of Contemporary Tourism Research, 1, 1-7. Doi: 10.30625/ijctr.320412

Ercis, A., \& Turk, B. (2016). In the frame of ethics consumption, consumer and the environment: The moderator role of eco-literacy. Çukurova University Faculty of Economics and Administrative Sciences, 20(2), 1-24. Retrieved from https://www.researchgate.net/publication/312585607.

Ergun, T., \& Cobanoglu, N. (2012). Sustainable development and environmental ethics. Ankara University Journal of Social Sciences, 3(1), 97-123. Doi: 10.1501/sbeder_0000000041.

Fagbayide, S., \& Abulude, F. (2018). Effects of human activities on water quality assessment of Ala River in Akure, Ondo State, Nigeria. World Journal of Environmental Research, 8(1), 37-44. https://doi.org/10.18844/wjer.v8i1.3486

Gay, L. R., \& Airasian, P. (2000). Educational Research Competencies for Analysis and Application (6th Edition). Ohio: Merrill an Imprint of Prentice Hall.

Guzel, P., Coknaz, D., \& Atalay Noordegraaf, M. (2009). Environmental aspects of sustainable development under the International Olympic Committee (IOC) and Olympic Organizations. Hacettepe Journal of Sport Sciences, 20(2), 59-69. Retrieved from https://dergipark.org.tr/tr/pub/sbd/issue/16389/171407.

International Union for Conservation of Nature and Natural Resources. (1980). World conservation strategy: Living resource conservation for sustainable development. Gland, Switzerland. Retrieved from https://portals.iucn.org/library/efiles/documents/WCS-004.pdf.

Karaca, C . (2007). Çevre, insan ve etik çerçevesinde çevre sorunlarına ve çözümlerine yönelik yaklaşımlar. Journal of Cukurova University Faculty of Economics and Administrative Sciences, 11(1). Retrieved from https://dergipark.org.tr/tr/pub/cuiibfd/issue/4155/54500. 
Sen, S., \& Temel, S., (2020). Understanding of sustainable development in terms of environmental ethics: A qualitative study. New Trends and Issues Proceedings on Humanities and Social Sciences. 7(1) pp 186-193

Karpudewan, M., Ismail, Z., \& Mohamed, N. (2009). The integration of green chemistry experiments with sustainable development concepts in pre-service teachers' curriculum: Experiences from Malaysia. International Journal of Sustainability in Higher Education, 10(2), 118-135. Doi: 10.1108/14676370910945936.

Kaypak, Ş . (2011). Küreselleşme sürecinde sürdürülebilir bir kalkınma için sürdürülebilir bir çevre. Karamanoglu Mehmetbey University Journal of Social and Economic Research, (1), 19-33. Retrieved from https://dergipark.org.tr/tr/pub/kmusekad/issue/10216/125569.

Mensah, J. \& Casadevall, S. R. (Reviewing editor) (2019.) Sustainable development: Meaning, history, principles, pillars, and implications for human action: Literature review. Cogent Social Sciences, 5(1), 1653531. Doi.org/10.1080/23311886.2019.1653531.

Miles, B. M., \& Huberman, A. M. (1994). Qualitative Data Analysis: An Extended Sourcebook (2nd edition). Thousand Oaks, CA: Sage.

Patton, M. Q. (2002). Qualitative Research \& Evaluation Methods (3rd edition). Thousand Oaks, CA: Sage.

Summers, M., Corney, G., \& Childs, A. (2004). Student teachers' conceptions of sustainable development: the starting-points of geographers and scientists. Educational Research, 46(2), 163-182. Doi: 10.1080/0013188042000222449.

World Commission on Environment and Development. (1987). Our common future. Retrieved from https://idl-bnc idrc.dspacedirect.org/bitstream/handle/10625/152/WCED v17 doc149.pdf?sequence=1.

Yıldıım, A., \& Şimşek, H. (2011). Sosyal Bilimlerde Nitel Araştırma Yöntemleri [Qualitative research methods in the social sciences] ( $8^{\text {th }}$ edition). Ankara: Seckin Publishing.

Yıldırım, O., \& Nuri, F. i. (2018). Sustainable development under the historical development process, presented at EconWorld2018@Lisbon, VII. International Conference on Economics, Lisbon, Portugal, 23-25 January $2018 . \quad$ Retrieved from https://lisbon2018.econworld.org/papers/Yildirim Nuri Sustainable.pdf. 